\title{
Nematode Community, Trophic Structure and Population Fluctuation in Soybean Fields*
}

\author{
Gilmar S. Gomes**, Shiou P. Huang \& Juvenil E. Cares \\ Universidade de Brasília, Departamento de Fitopatologia, Brasília, CEP 70.910-900
}

(Accepted for publication on 20/11/2002)

Corresponding author: Shiou Pin Huang

GOMES, G.S., HUANG, S.P. \& CARES, J.E. Nematode community, trophic structure and population fluctuation in soybean fields. Fitopatologia Brasileira 28:258-266. 2003.

\begin{abstract}
Temporal (monthly in three fields for 12 months) and spatial (once in 23 fields during March-April) samplings were conducted in the major soybean (Glycine max)-growing region of the Brazilian Federal District. Fifty-three nematode genera were found in both samplings, but 13 were detected only by the temporal sampling, and one only by the spatial sampling. Fifty-three percent were plantparasites, $35 \%$ were bacterivores, and about $12 \%$ were fungivores, predators and omnivores constituted the community that was dominated by the genera Helicotylenchus ( $40 \%$ of total abundance), Acrobeles (15\%), Cephalobus (7.6\%), Meloidogyne (5.6\%) and Pratylenchus (4.9\%). Heterodera glycines was not found in this study. There were no differences in ten ecological measurements [Ds, H', Es, T, FF/BF, (FF+BF)/PP, MI, PPI, mMI, and Dorylaimida (\%)] between the two sampling types, but differences in indexes $d$ and $\mathrm{J}^{\prime}$. Plant

parasite populations dropped at the end of the crop cycle, remained at low levels during the dry season and the seedling period, then increased again in the crop-growing season. Fungivores maintained their low populations throughout the year, increasing only in June and July, the post-harvest period, when soil fungi decomposed root tissue. The population of bacterivores slightly declined during the dry season and the initial rainy season, but peaked in the middle of the rainy season, apparently associated with soil humidity. In the five most abundant nematodes, those of Acrobeles and Pratylenchus were more populous in wet soils, Cephalobus and Meloidogyne adapted well in dry soils, but Helicotylenchus survived abundantly in a wide range of soil moisture.

Additional keywords: Glycine max, population dynamics, nematode ecology, temporal and spatial samplings, and functional groups.
\end{abstract}

\section{RESUMO}

Comunidade de nematóides, estrutura trófica e flutuação populacional em plantações de soja

Amostragens temporal (mensalmente em três campos por 12 meses) e espacial (uma vez, em 23 campos, de março a abril) foram feitas na principal região sojícola do Distrito Federal. Nos dois tipos de amostragem foram encontrados 53 gêneros de nematóides, sendo 13 deles detectados apenas pela temporal e um somente pela espacial. Do total, $53 \%$ foram fitoparasitos, $35 \%$ bacteriófagos e cerca de $12 \%$ micófagos, predadores e onívoros. Esses constituíram a comunidade de nematóides, dominada por Helicotylenchus (40\% da abundância total), Acrobeles (15\%), Cephalobus (7,6\%), Meloidogyne (5,6\%) e Pratylenchus (4,9\%). Heterodera glycines não foi encontrado neste estudo. Não houve diferença quanto aos índices Ds, H', Es, T, FF/BF, (FF+BF)/PP, MI, PPI, mMI e Dorylaimida (\%) entre as duas amostragens, mas houve diferença quanto aos índices d e J'. Os fitoparasitas tiveram populações reduzidas no final do ciclo da cultura, se mantiveram em nível baixo na estação seca e no período de desenvolvimento inicial das plantas, aumentando durante o crescimento das mesmas. Os micófagos se mantiveram em baixa população durante o ano, mas se elevaram em junho e julho, período de pós-colheita, em que raízes se encontravam em decomposição por fungos do solo. Os bacteriófagos tiveram suas populações ligeiramente reduzidas durante a seca e a fase inicial das chuvas, mas se elevaram no meio da estação chuvosa, estando, aparentemente, associadas à alta umidade do solo. Dentre os cinco gêneros mais abundantes, Acrobeles e Pratylenchus povoaram mais solos úmidos, enquanto Cephalobus e Meloidogyne adaptaram bem em solos secos, mas Helicotylenchus sobreviveu abundantamente numa grande faixa de umidade.

\section{INTRODUCTION}

Nematodes are widely distributed in soil, and their communities are made up of diverse species that, according to their feeding habits, can be classified into five major groups: plant parasites, bacterial and fungal feeders, predators and omnivores. The role of nematodes in a soil ecosystem is to

\footnotetext{
*Part of the Master Dissertation of the first author. Universidade de Brasília. (1996)

**CAPES fellowship
}

recycle nutrients by feeding plant tissue and microorganisms and liberating minerals for easy absorption by plant roots. Due to different nematodes having different life spans and different reproductive and survival capacities, the nematode community has been used as an ecological bioindicator to reflect environmental changes (Freckman, 1982; Samoiloff, 1987; Bongers, 1990). The abundance of each species in the community can be transformed into ecological indexes and parameters to measure community changes in diversity and trophic structure, and further to assess soil disturbance levels 
and decomposition pathways. Recently, many nematologists have focused on the changes of nematode community structure in different vegetation systems, ranging from native to intensified agriculture systems (Niblack, 1989; Hyvonen \& Persson, 1990; Coleman et al., 1991; Wasilewska, 1991; Freckman \& Ettema, 1993; Neher \& Campbell, 1994).

When the occurrence of soybean cyst nematodes (Heterodera glycines Ichinohe, 1952) was reported in Brazil in 1991-1992, it was limited to three isolated fields, Nova Ponte (MG), Campo Verde (MT), and Chapadão do Céu (GO) (Silva, 1999). At present, the infestation has spread to about two millions hectares, including 70 soybean-growing counties in seven states (Minas Gerais, Goiás, Mato Grosso, Mato Grosso do Sul, São Paulo, Paraná and Rio Grande do Sul) (Silva, 1999) causing an estimated production loss of 216,000 tons of soybean [Glycine max (L.) Merrill] (Goellner, 1995). On the other hand, the production of soybean by the Program of Managed Settlement in the Federal District ("Programa de Assentamento Dirigido no Distrito Federal") (PAD/DF) has increased considerably in the last decade, now contributing about $90 \%$ of total district production. The Brazilian Federal District is in Central Brazil, the major soybean-producing region in the country, with about $41,7 \%$ of total national production (CONAB/DIPLA, 2002). So far, there are no data on the soybean cyst nematode for this major soybean-growing region.

Nematodes are microorganisms that can survive within many small patches in soil environment, but their life processes are very sensitive to climatic variations. Thus, their communities can be influenced by habitat heterogeneity and successional changes. Results from spatial sampling do not show seasonal effects, whereas those from temporal sampling neglect geographic variations. It is valuable to compare the results from the two sampling types to provide further information, as both types of sampling are laborious and may not be executed in the same project.

Therefore, the objectives of this study were to characterize five ecological aspects of the nematode communities: abundance, diversity, trophic function, soil disturbance and decomposition pathway, in the major soybeangrowing region of the Federal District and adjacent areas, with special attention to the existence of soybean cyst nematodes. This study was also to compare the results from spatial and temporal samplings, and further to describe population patterns of five different trophic groups and five most-abundant nematode genera, and their relations to each other and to soil water contents and monthly precipitation.

\section{MATERIALS AND METHODS}

The study was carried out at PAD/DF, the major soybean-producing region in the Brazilian Federal District. The climate of this region is characterized by two distinct seasons: one dry (from May to September) with almost no precipitation, and one wet (from October to April) with a total precipitation of approximately $1,500 \mathrm{~mm}$, mostly concentrated in November, December and January. The soil is typical sandy loam known as red latosol ('latossolo vermelho'), and soil temperature fluctuates between $26^{\circ} \mathrm{C}$ in the summer and $15^{\circ} \mathrm{C}$ in the winter (EMBRAPA, 1978).

Two types of soil samplings were made in this study. One was a spatial sampling made once in 23 soybean fields at relatively random distribution in this region between March 21-April 27, 1994. Another was a temporal sampling made monthly in three (fields 14, 20 and 22) of the 23 fields for 12 months. In this study, soybean was harvested from May to June and next seeded from October to November, with a free fallow between the two periods. During the fallow period, grasses, and dicotyledonous weeds, such as Acanthospermum australe (Loefl.) Kuntze, Bidens pilosa L. and Emilia sonchifolia DC, dominated the plant community.

Within 23 soybean fields, 18 were planted with cultivar FT-Cristalina, and the other five fields were planted with different cultivars [field 20 with cv. FT-Seriema, field 1 with cv. FT-Estrela, field 9 with cv. FT-11 (Alvorada), field 16 with cv. EMGOPA-305, and field 5 with cv. Doko]. The information about the 23 fields was recorded (Gomes, 1996). The sampling area (about $1.5 \mathrm{ha}$ ) in each field was divided into five zigzag rows, 12 points/row and each point at 0-20 $\mathrm{cm}$ depth a sample was collected by a steel tube with $3 \mathrm{~cm}$ in diameter. The soil samples from 12 points were composted to one sample from which $1 \mathrm{~kg}$ of homogenized soil was processed for nematode extraction. Another $50 \mathrm{~g}$ of soil was placed in an oven at $100{ }^{\circ} \mathrm{C}$ for $24 \mathrm{~h}$, and the soil water contents were calculated by the reduction of soil weight after heating. At the same time, the precipitation records during the sampling periods were obtained from the local weather agency.

For nematode extraction, $1 \mathrm{~kg}$ of soil sample was placed in 91 of water, and then passed through a 50-mesh (297 $\mu$ m pore-openning) screen. Nematodes were collected by 400 -mesh $(37 \mu \mathrm{m})$ screens. The soil suspensions were rotated at 2,000 rpm for $20 \mathrm{~s}$, and nematodes in the supernatant were collected by a 500 mesh-screen with a $26 \mu \mathrm{m}$ pore-openning. The residue in the centrifuge tubes was re-suspended in sucrose solution (456 g/l), and re-rotated and re-collected by the same way. Nematode samples were preserved in $15 \mathrm{ml}$ of Golden solution (3\%) (Hopper, 1970). All nematodes in $1 \mathrm{ml}$ randomly removed from the solution were counted, and the total number calculated by the mean of three counts $\mathrm{x} 15 \mathrm{ml}$. After infiltration with glycerin (Seinhorst, 1959) and mounted on slides, one hundred nematodes were randomly selected for identification at a generic level under a compound microscope (400-1,000x).

The data were then transformed into the following measurements as formulas previously described (Magurran, 1988; Krebs, 1994): absolute frequency, total abundance, relative abundance, trophic groups (bacterial and fungal feeders, plant parasites, omnivores and predators) group allocation after Yeates et al. (1993). If one nematode had two types of feeding habits, its population number was divided by two for each one. Other measures used were the species richness index $[d=(S-1) / \log N$, where $S=$ no. of genera, 
and $\mathrm{N}=$ total no. of nematodes], Simpson's diversity index [Ds $=1-\Sigma\left(\mathrm{p}_{\mathrm{i}}\right)^{2}$, where, $\mathrm{p}_{\mathrm{i}}=$ percent of genus " $\mathrm{i}$ " in the total abundance], Shannon-Weaver's diversity index $\left[\mathrm{H}^{\prime}=-\Sigma \mathrm{p}_{\mathrm{i}}\right.$ $\log _{2} \mathrm{p}_{\mathrm{i}}$ ], evenness of Simpson's diversity index (Es $=$ Ds/ $\mathrm{Ds}_{\max }$, where $\left.\mathrm{Ds} \mathrm{m}_{\max }=1-1 / \mathrm{S}\right)$ and of Shannon-Weaver's diversity index $\left(J^{\prime}=H^{\prime} / H^{\prime} \max\right.$, where $\left.H^{\prime} \max =\log _{2} S\right)$, trophic diversity index $\left[\mathrm{T}=1 / \Sigma\left(\mathrm{p}_{\mathrm{i}}\right)^{2}\right.$, where $\mathrm{p}_{\mathrm{i}}=$ relative abundance of one trophic group], the ratios of fungivore/bacterivore $(\mathrm{FF} / \mathrm{BF})$ and of (fungivore+bacterivore)/plant parasite $[(\mathrm{FF}+\mathrm{BF}) / \mathrm{PP}]$, and percentages of criconematids and of dorylaimids in the population. Also, the three indexes [maturity index (MI), plant parasitic index (PPI) and modified maturity index (mMI)] to measure soil disturbance were calculated by the same formula, $\Sigma \mathrm{v}_{\mathrm{i}} \times \mathrm{f}_{\mathrm{i}}$ (where, $\mathrm{v}_{\mathrm{i}}=\mathrm{c}$-p value from 1 to 5 for genus " $i$ ", and $f_{i}=$ relative frequency of genus " $i$ "). The $\mathrm{mMI}$ was applied to all soil nematodes, the MI applied to all soil nematodes except plant parasitic nematodes in Tylenchina, Trichodoridae and Longidoridae, and the PPI only to these plant parasitic nematodes. These measurements were then compared with each other in the two sampling types. In the temporal sampling, population fluctuations of the five trophic groups and of the five most abundant genera were observed for 12 months, and related to soil water content in each sample and local annual precipitation.

\section{RESULTS}

In 295 soil samples (180 in the temporal and 115 in the spatial samplings), 29,500 nematodes were identified, and assigned to 53 genera (Table 1). The numbers of genera were 45 in field 22, 48 in field 20, and 47 in field 14, with a total of 52 genera in the temporal sampling, in contrast with 40 in the spatial sampling (Figure 1). Total abundance was 5,208 nematodes $/ \mathrm{kg}$ of dry soil in the temporal sampling, and 5,539 in the spatial sampling. More than $70 \%$ of total abundance belonged to five genera: Helicotylenchus (about 39\%), Acrobeles (15\%), Cephalobus (9\%), Meloidogyne (4\%) and Pratylenchus (4\%). In the spatial sampling, plant parasitic nematodes occupied more than $50 \%$ of relative abundance, bacterial feeders $35 \%$, and the rest consisted of omnivores, fungal feeders and predators with less than $6 \%$ of each. The soybean cyst nematode, $H$. glycines, was not found in both samplings.

The values of ten measurements [Ds, $\mathrm{H}^{\prime}, \mathrm{Es}, \mathrm{T}, \mathrm{FF} / \mathrm{BF}$, $(\mathrm{FF}+\mathrm{BF}) / \mathrm{PP}, \mathrm{MI}, \mathrm{PPI}, \mathrm{mMI}$ and Dorylaimida $(\%)]$ were not different between the temporal and the spatial samplings, but the values of two indexes ( $\left(\mathrm{d}\right.$ and $\mathbf{J}^{\prime}$ ) were different (Table 2).

The curves of soil water contents in the three temporalsampling fields were similar to each other. The soil water contents reached the highest points (between 25 and 28\%) in June, dropped drastically to the lowest points (below 15\%) in August, September and October, then increased to about $25 \%$ in December, and fluctuated tending to decline from March to May (Figure 2A). Precipitation was low (25 to $75 \mathrm{~mm} / \mathrm{month}$ ) in April, May and June, almost zero in July, August and September, and high ( 90 to $200 \mathrm{~mm} / \mathrm{month}$ ) from October to March (Figure 2B).
Nematode populations reached their highest peak in June, the harvest month, and fluctuated at low and stable levels in the other months (Figure 3). The populations of plant parasitic nematodes were high almost all year long, but drastically dropped in June and July at the post harvest period (Figure 4). The exact opposite occurred in populations of fungal feeders. The bacterial feeders also remained relatively stable at 24 to $36 \%$ in the most of time, but peaked to $35-45 \%$ in December and January, strongly indicating their association with soil humidity (about $25 \%$ soil water content) (Figure 2, Table 3). The predators and omnivores population levels were low and stable (below 10\%) for the whole year, except for a peak in predators of $10 \%$ in July that was possibly associated with the high population of fungal feeders during this period (Table 3).

The population of Helicotylenchus spp. was relatively abundant at high levels (over $30 \%$ of relative abundance) for almost the whole year, but drastically dropped to $12 \%$ in May, 1994 and slightly declined to 26\% in January 1995 (Figure 5). The populations of Cephalobus spp. reached two peaks, in April and in October, about $15 \%$ of relative abundance, and fluctuated between 4 to $8 \%$ in the other months, whereas the populations of Acrobeles spp. fluctuated between 9 and $18 \%$ from March to October, but increased to 20-30\% from November to February. The populations of Meloidogyne spp. and Pratylenchus spp. were at high levels (7.9 and 5.6\%, respectively) in April, but drastically dropped to 3-4\% in May and June. Meloidogyne spp. returned to its high level (7.3\%) in July and August, and afterward fluctuated between 4 and $6 \%$ until March. On the contrary, the population of Pratylenchus spp. declined and maintained at low level (2$3 \%$ ) in the same period, but began to peak from $4.2 \%$ in January to $7.6 \%$ in March.

Within the five trophic groups, strong relationships were found between plant parasites and fungal feeders, between plant parasites and predators, and between fungal feeders and predators (Table 3). Within the five most abundant nematode genera, high negative correlations were found between Acrobeles spp. and Cephalobus spp., Helicotylenchus spp. and Acrobeles spp., and Cephalobus spp. and Pratylenchus spp. Soil water content was related positively to bacterial feeders, Acrobeles spp. and Pratylenchus spp., and negatively to plant parasites, Cephalobus spp. and Meloidogyne spp. Annual precipitation was related positively to omnivores and Acrobeles spp., and negatively to Cephalobus spp. and Meloidogyne spp. The correlation among the other partners was low $(<0.40)$. In general, nematodes in trophic groups and abundant genera were related more to soil water contents than to annual precipitations.

\section{DISCUSSION}

In this study, there were not too many differences between the two sampling types in the twelve measurements for ecological assessment. The differences were only found in generic richness (d) and evenness of Shannon-Weaver's 
Nematode community, trophic structure and population fluctuation in soybean fields

TABLE 1 - Abundance and frequency of soil nematodes found in temporal and spatial samplings made on soybean (Glycine max) fields in Brazilian Federal District

\begin{tabular}{|c|c|c|c|c|c|c|}
\hline \multirow[b]{2}{*}{ TAXA } & \multirow[b]{2}{*}{$\begin{array}{l}\text { trophic } \\
\text { group }\end{array}$} & \multirow[b]{2}{*}{ C-P value } & \multicolumn{2}{|c|}{ Temporal sampling* } & \multicolumn{2}{|c|}{ Spatial sampling } \\
\hline & & & $\begin{array}{c}\text { Relative } \\
\text { abundance (\%) }\end{array}$ & $\begin{array}{c}\text { Absolute } \\
\text { Frequency (\%) }\end{array}$ & $\begin{array}{c}\text { Relative } \\
\text { abundance }(\%)\end{array}$ & $\begin{array}{l}\text { Absolute Frequency } \\
\qquad(\%)\end{array}$ \\
\hline Acrobeles & $\mathrm{BF}$ & 2 & 15.86 & 100 & 14.37 & 100 \\
\hline Acrobeloides & $\mathrm{BF}$ & 2 & 1.72 & 61.11 & 0.16 & 10.43 \\
\hline Akrotonus & PR & 5 & 0.26 & 17.78 & 0.01 & 0.86 \\
\hline Alaimus & $\mathrm{BF}$ & 4 & 0.62 & 33.89 & 0.10 & 8.69 \\
\hline Aphelenchoides & FF, PP & 2 & 0.39 & 18.33 & 1.10 & 46.96 \\
\hline Aphelenchus & FF, PP & 2 & 2.84 & 85.00 & 1.03 & 46.09 \\
\hline Aporcelaimellus & OM, PR & 5 & 0.45 & 22.78 & 0.24 & 15.65 \\
\hline Aporcelaimium & OM PR & 5 & 0.41 & 21.11 & 0.05 & 4.35 \\
\hline Aporcelaimus & OM, PR & 5 & 0.04 & 3.33 & 0.17 & 13.04 \\
\hline Carcharolaimus & PR & 5 & 0.06 & 3.33 & 0.35 & 10.43 \\
\hline Cephalenchus & PP & 2 & 0.01 & 1.11 & -- & -- \\
\hline Cephalobus & $\mathrm{BF}$ & 2 & 7.66 & 98.33 & 11.76 & 99.13 \\
\hline Chiloplachus & $\mathrm{BF}$ & 2 & 0.44 & 28.89 & 0.11 & 8.70 \\
\hline Chromadorita & $\mathrm{FF}$ & 3 & 0.02 & 1.67 & 0.01 & 0.87 \\
\hline Coslenchus & PP & 2 & 0.01 & 0.56 & 0.02 & 0.87 \\
\hline Crassolabium & PR & 4 & 0.03 & 2.78 & -- & -- \\
\hline Criconemella & PP & 3 & 0.01 & 0.56 & -- & -- \\
\hline Diphtherophora & $\mathrm{FF}$ & 3 & 0.21 & 15.00 & 0.15 & 8.69 \\
\hline Discolaimoides & PR & 4 & 0.11 & 7.78 & -- & -- \\
\hline Discolaimus & PR & 4 & 0.31 & 20.56 & 0.33 & 11.30 \\
\hline Ditylenchus & FF,PP & 2 & 0.51 & 30.56 & 1.16 & 47.82 \\
\hline Dorylaimoides & $\mathrm{OM}$ & 4 & 3.58 & 85.00 & 1.77 & 63.48 \\
\hline Dorylaimus & $\mathrm{OM}$ & 4 & 0.03 & 2.22 & 0.02 & 1.73 \\
\hline Ecumenicus & PR & 4 & 0.13 & 12.22 & 0.03 & 4.34 \\
\hline Enchodelus & $\mathrm{OM}$ & 4 & 0.03 & 2.22 & -- & -- \\
\hline Eucephalobus & $\mathrm{BF}$ & 2 & 2.97 & 86.67 & 2.88 & 65.22 \\
\hline Helicotylenchus & PP & 3 & 38.17 & 100 & 40.25 & 100 \\
\hline Labronema & $\mathrm{PR}, \mathrm{OM}$ & 4 & 0.42 & 22.22 & 0.92 & 48.70 \\
\hline Laimydorinae & $\mathrm{OM}$ & 4 & 1.05 & 45.00 & 0.44 & 25.22 \\
\hline Latocephalus & $\mathrm{BF}$ & 2 & 0.07 & 6.11 & 0.19 & 6.95 \\
\hline Lelenchus & PP & 2 & 0.02 & 2.22 & -- & -- \\
\hline Malenchus & PP & 2 & $--* *$ & -- & 0.06 & 5.21 \\
\hline Meloidogyne & PP & 3 & 5.66 & 97.78 & 3.23 & 59.13 \\
\hline Mesodorylaimus & $\mathrm{OM}$ & 4 & 0.42 & 14.44 & 0.23 & 8.70 \\
\hline Mononchus & PR & 4 & 0.12 & 7.78 & 0.20 & 11.30 \\
\hline Monhystera & $\mathrm{BF}$ & 1 & 0.24 & 13.33 & -- & -- \\
\hline Nygolaimoides & PR & 4 & 0.20 & 16.11 & -- & -- \\
\hline Paraxonchium & OM, PR & 5 & 0.63 & 30.56 & 0.43 & 25.22 \\
\hline Plectus & $\mathrm{BF}$ & 2 & 0.02 & 1.67 & -- & -- \\
\hline Pratylenchus & PP & 3 & 4.02 & 93.33 & 4.92 & 91.30 \\
\hline Prismatolaimus & $\mathrm{BF}$ & 3 & 0.04 & 3.89 & 0.34 & 17.39 \\
\hline Prodorylaimium & $\mathrm{OM}$ & 4 & 0.04 & 2.78 & -- & -- \\
\hline Qudsianematinae & $\mathrm{PR}, \mathrm{OM}$ & 4 & 1.69 & 66.67 & 1.23 & 53.91 \\
\hline Rhabditis & $\mathrm{BF}$ & 1 & 2.10 & 75.00 & 5.82 & 92.17 \\
\hline Teratocephalus & $\mathrm{BF}$ & 3 & 0.12 & 9.44 & 0.02 & 0.86 \\
\hline Thonus & $\mathrm{PR}, \mathrm{OM}$ & 4 & 3.97 & 78.33 & 2.21 & 73.04 \\
\hline Thorneella & PR & 4 & 0.47 & 27.78 & 0.18 & 10.43 \\
\hline Tobrilus & $\mathrm{PR}, \mathrm{OM}$ & 3 & 0.02 & 1.11 & -- & -- \\
\hline Trichodorus & PP & 4 & 0.69 & 30.00 & 1.81 & 26.09 \\
\hline Tylencholaimus & FF & 4 & 0.42 & 18.33 & -- & -- \\
\hline Tylenchus & FF, PP & 2 & 0.68 & 31.11 & 1.65 & 66.09 \\
\hline Unidentified genus $1 * * *$ & $\mathrm{OM}$ & 4 & 1.05 & 45.00 & 0.44 & 25.22 \\
\hline Unidentified genus 2 & $\mathrm{BF}$ & 1 & 0.02 & 1.67 & 0.06 & 0.87 \\
\hline Unidentified genus 3 & $\mathrm{OM}$ & 4 & 0.01 & 0.56 & -- & -- \\
\hline Total abundance\# & & & 5208 & & 5539 & \\
\hline Total frequency & & & & 180 & & 115 \\
\hline Total taxa & & & 52 & & 40 & \\
\hline
\end{tabular}

*The temporal sampling was made monthly in three different fields for 12 months, and the spatial sampling was done once in 23 different fields during March-April; **Nematodes not found; ***Unidentified genus 1 belonged to Laimydorinae, unidentified genus 2 to Diplogasteridae, and unidentified genus 3 to Lordellonematinae;

\#Total abundance $=$ number of nematodes $/ \mathrm{kg}$ of dry soil. 


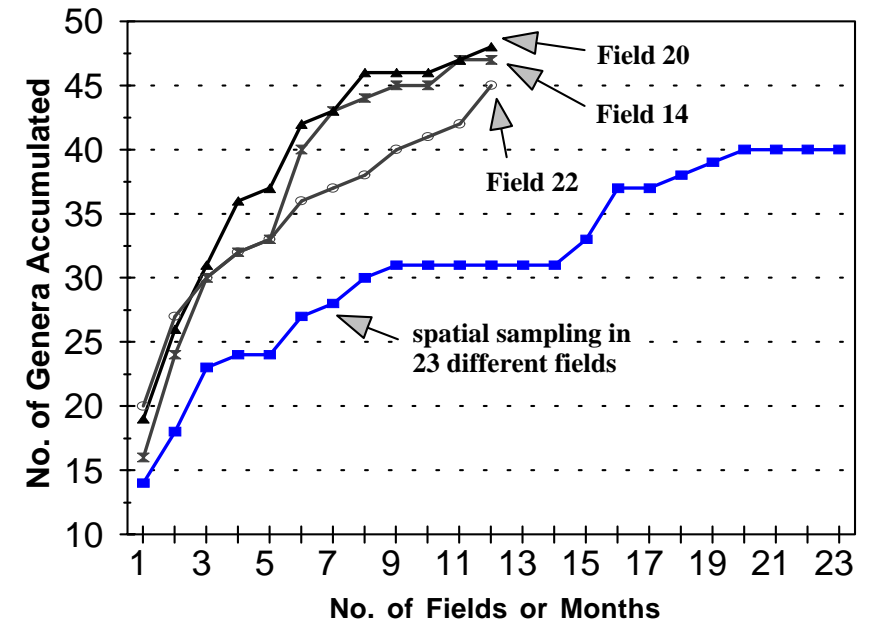

FIG. 1 - Relations between accumulated numbers of nematode genera and numbers of sampling fields (23 fields in the spatial sampling) or months (three fields for 12 months in the temporal sampling). The samplings were conducted in the major soybean (Glycine max)-growing region of the Brazilian Federal District, 1994-1995.

index $\left(\mathrm{J}^{\prime}\right)$ that were higher in the temporal sampling than in the spatial one. There were more genera found in the temporal sampling ( 52 genera) than in the spatial sampling ( 40 genera). To reach 40 genera, 20 different fields were needed in the spatial sampling, and six monthly samplings in field 20 , seven in field 14, and ten in field 22. Thirteen rare genera (less than $0.5 \%$ of total abundance) were found in the temporal sampling only, including three plant parasites, two bacterial feeders, one fungal feeder, and seven predators and omnivores, only one genus (Malenchus) was found in the spatial sampling. This indicates that more rare nematodes surviving in narrow niches or small patches in limited month(s) could be found in the temporal sampling than in the spatial sampling.

The ratio $\mathrm{FF} / \mathrm{BF}$ is an indicator of food chain decomposition (Sohlenius \& Sandor, 1987). Neher \& Campbell
(1994) measured the ratio at 0.11 for an annual soybean crop, and 0.21 for a perennial plant, tall-fescue. Freckman \& Ettema (1993) estimated 0.54, and McSorley \& Frederick (1996) 0.180.27 for soybean. Boström \& Sohlenius (1986) found the abundance of bacterivores lower in annual crop than perennial plants, and Neher \& Campbell (1994) considered the variation of abundance higher in bacterivores than in fungivores. In our study, the ratio of FF/BF in soybean plantations was 0.10 +0.04 in the spatial sampling, and $0.30+0.30$ in the temporal sampling. The high variations in the temporal sampling were attributed to high abundance of fungivores in June and July, and of bacterivores in December and January. It suggests that the high abundance of fungivores was related to the degradation of root tissues by fungi after harvest, and of bacterial feeders related to the high population of bacteria during the rainy season.

Neher \& Campbell (1994) found PPI $=2.82$ for soybean plantations, whereas Freckman \& Ettema (1993) reported $\mathrm{PPI}=2.51$ and $\mathrm{MI}=1.78$ in soybean fields. The low indices indicate large numbers of colonizers (short life cycle, high reproductive ratio and tolerance to environmental disturbance), whereas the high indicate a high degree of persistence in the population (long life cycle, low reproductive ratio and sensitivity to environmental change). In this study, PPI were 2.62 in the spatial sampling and 2.72 in the temporal sampling. But MI were higher (2.95 and 3.10 in the spatial and temporal samplings, respectively) than those previously reported, indicating that these sampling fields were less disturbed than the fields studied by Freckman \& Ettema (1993), probably due to shorter history of soybean plantation in PAD/ DF than the experimental fields in the United States.

The population of dorylaimids in the nematode community was sensitive to agricultural practices (plowing, fertilizers and pesticides), and was therefore used as an indicator of environmental disturbance (Thomas, 1978; Sohlenius \& Wasilewska, 1984). A high percentage (>25\%) of dorylaimids indicates less human intervention in the field,

TABLE 2 - Measurements of spatial and temporal samplings on nematode communities in soybean (Glycine max) fields localized in PAD/DF

\begin{tabular}{lcc}
\hline \hline Measurement & Spatial sampling\# & Temporal sampling \\
\hline Genus richness (d) & $3.21 \pm 0.45(2.57-4.56) * \$$ & $5.03 \pm 0.52(3.97-6.10)$ \\
Simpson's diversity index (Ds) & $0.77 \pm 0.06(0.55-0.87)$ & $0.78 \pm 0.05(0.63-0.86)$ \\
Shannon-Weaver's diversity index (H') & $0.87 \pm 0.06(0.75-0.99)$ & $0.93 \pm 0.08(0.73-1.10)$ \\
Evenness of Shannon-Weaver's index (J') & $0.62 \pm 0.05(0.53-0.70) \$$ & $0.85 \pm 0.08(0.66-1.00)$ \\
Evenness of Simpson's index (Es) & $0.81 \pm 0.05(0.69-0.89)$ & $0.82 \pm 0.05(0.66-0.89)$ \\
Trophic diversity index (T) & $2.38 \pm 0.21(1.73-2.63)$ & $2.90 \pm 0.53(2.41-4.13)$ \\
Fungivores/bacterivores (FF/BF) & $0.10 \pm 0.04(0.03-0.19)$ & $0.30 \pm 0.30(0.02-1.58)$ \\
(Fungivores+bacterivores)/plant parasites ((FF+BF)/PP) & $0.78 \pm 0.28(0.29-1.68)$ & $1.07 \pm 0.68(0.31-2.71)$ \\
Maturity index (MI) & $2.95 \pm 0.15(2.67-3.34)$ & $3.10 \pm 0.22(2.67-3.60)$ \\
Plant parasitic index (PPI) & $2.62 \pm 0.11(2.45-2.86)$ & $2.72 \pm 0.12(2.56-3.09)$ \\
Modified maturity index (mMI) & $2.92 \pm 0.11(2.67-3.16)$ & $3.01 \pm 0.18(2.63-3.40)$ \\
Dorylaimida (\%) & $9.19 \pm 2.36(5.0-14.20)$ & $15.16 \pm 5.92(6.40-34.80)$ \\
\hline
\end{tabular}

"Spatial sampling was made once in 23 fields during March-April, 1994, and temporal sampling done monthly in 3

fields for 12 months (April, 1994-March, 1995).

*average + standard deviation(minimum-maximum).

$\$$ not overlapped at the values of average + standard deviation in the two sampling types. 
Nematode community, trophic structure and population fluctuation in soybean fields
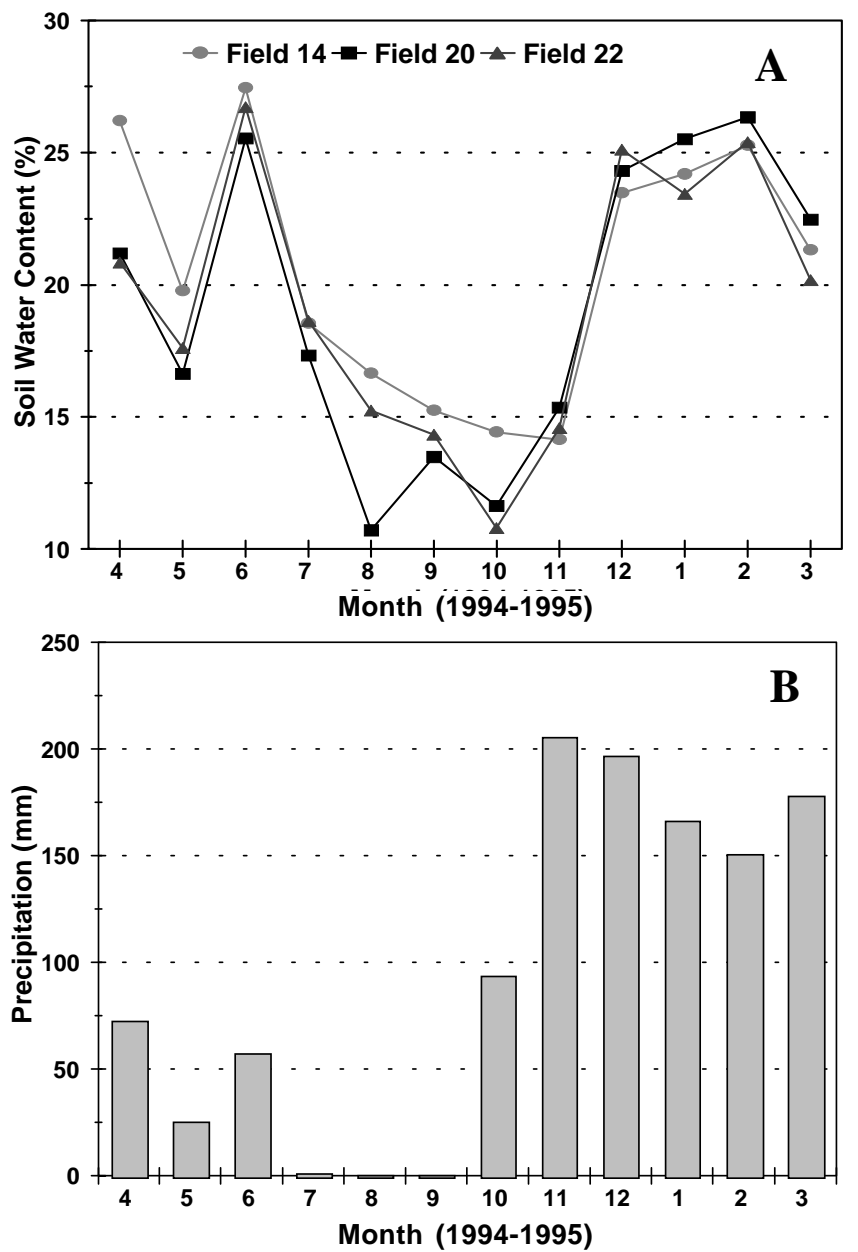

FIG. 3 - Soil water contents (A) collected monthly from three soybean (Glycine max) fields in the temporal sampling for 12 months, and local precipitation record (B) in the PAD/DF, the major soybeangrowing region of the Brazilian Federal District.

while a low percentage indicates the contrary. In this work, the percentages of dorylaimids in the nematode community were inconsistent. The percentages in some fields were as high as $34.8 \%$, possibly because the fields had only recently been cultivated with soybean from native vegetation. Some were as low as $5 \%$, indicating that the cultivation had been going on for a long time. Most of criconematids (superfamily Criconematoidea) are sedentary ectoparasites that are sensitive to environmental disturbance such as plowing. That is why they generally show high populations among perennial plants such as fruit trees, forest plants and wild vegetation, and low populations in cultivated annual plants (Cares \& Huang, 1991). In the present study, only one individual of Criconemella sp. was found in all the samplings, confirming past results.

In this study, three plant parasitic genera, Helicotylenchus, Meloidogyne and Pratylenchus, were considered to be the most important plant parasites in the region of PAD/DF. The root-knot nematodes, mostly, $M$. javanica (Treub) Chitwood, 1949 and M. incognita (Kofoid \& White) Chitwood, 1949, are well known as the most

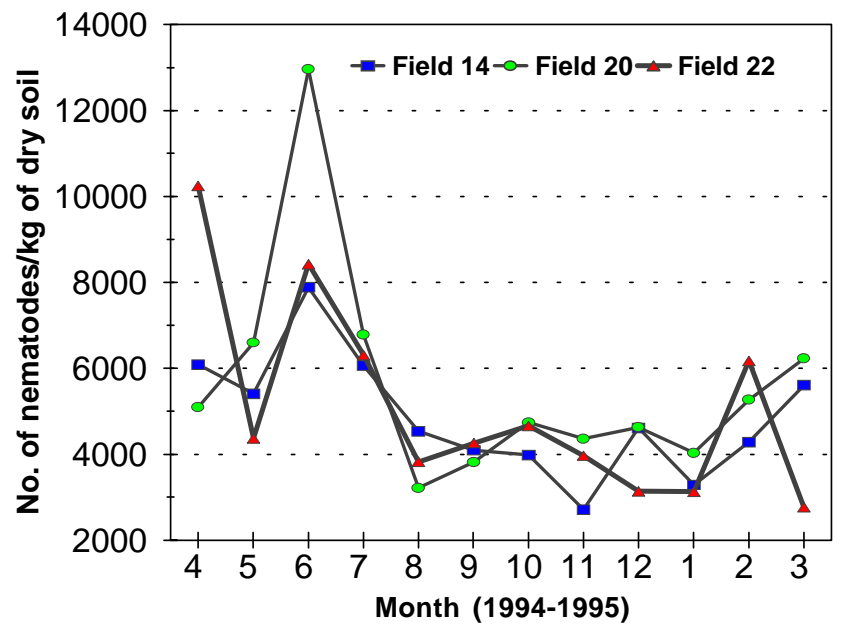

FIG. 4 - Total abundance of soil nematodes in the temporal sampling made in three soybean(Glycine max) fields for 12 months in PAD/DF, the major soybean-growing region of the Brazilian Federal District.

economically important nematodes in soybean yield production in the tropical region (Sasser, 1979). Pratylenchus spp., an aggressive migratory endoparasite, is the second most important plant parasitic nematode in this region. Helicotylenchus spp. [some identified as H. dihystera (Cobb, 1893) Sher, 1961] is the most abundant (20-66\% of total abundance) and the most frequent nematode (found in all samples) in this region, and is expected to cause some levels of yield loss, although its pathogenicity in soybean has not been proved. Other plant parasites were also found, but their population levels were quite low, and might not play an important role in soybean yield reduction.

In general, nematode population drastically declined in July and August, since the nematode community was constituted mainly of plant-parasitic nematodes that significantly dropped their populations in the final growing cycle of soybean. The low population of plant parasitic nematodes in June and July coincided with the post-harvest period. The population quickly grew in August, mostly due to the populations of Meloidogyne spp. and Helicotylenchus spp. that could survive well with grasses and broad leaf weeds. The next decline coincided with the final dry season (September), with weed host removal in October and with little root growth in the seedling period from November to January. After this period, their populations fluctuated with a tendency to increase until May, the final growing cycle, with an abundance of root biomass possibly contributing to the increase.

The plant parasitic nematode Helicotylenchus spp. showed very high populations during all study periods. There were many juveniles after the harvest of soybean, possibly indicating that a high number of eggs were hatching at the end of soybean cycle. Populations of root-knot nematode, Meloidogyne spp. increased after the harvest in July and August. Similarly, high populations of M. javanica were found after the end of the growing cycles of okra [Abelmoschus esculentus (L.) Moench] and carrot (Daucus carota L.), which 

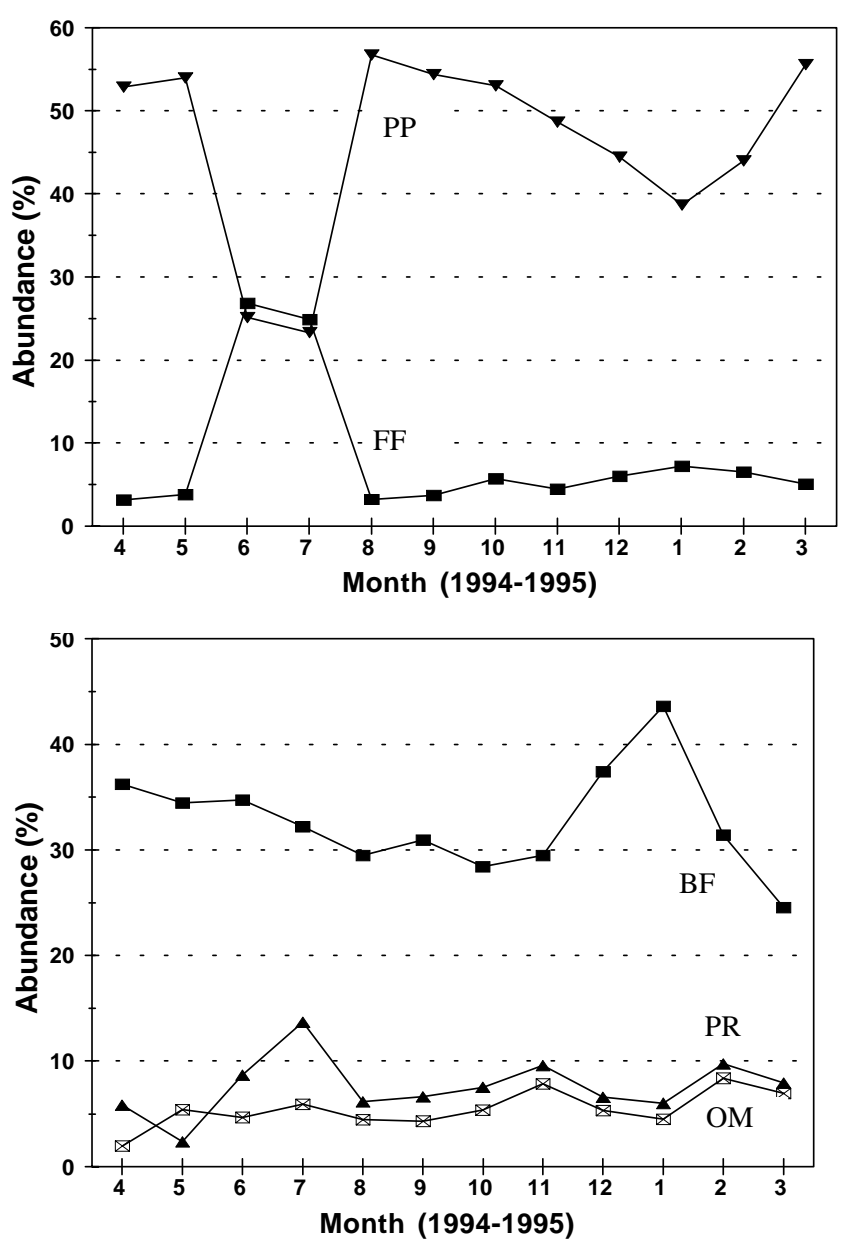

FIG. 4 - Population fluctuations of five trophic groups collected monthly from three soybean (Glycine max) fields for 12 months in the temporal sampling, where plant parasites (PP), fungal feeders $(\mathrm{FF})$, bacterial feeders $(\mathrm{BF})$, predators $(\mathrm{PR})$ and omnivores $(\mathrm{OM})$. The samplings were conducted in PAD/DF, the major soybeangrowing region of the Brazilian Federal District.

Huang \& Porto (1988) attributed to a high degree of egg hatching from the egg masses. Soon after egg hatching, the population decreased drastically as available roots quickly decreased. The population of Pratylenchus spp., the migratory endoparasitic nematode, gradually decreased from April to September, maintained a low population level until December, that began to increase from January through March, coinciding with the growing soybean root system. Soil water contents played an important role in population fluctuation, negatively influencing Meloidogyne spp., positively influencing Pratylenchus spp., and having less of an affect on Helicotylenchus spp. (Table 3).

Species of Acrobeles and Cephalobus were the most abundant and frequent bacterial feeders in soybean cultivated soil. From the population fluctuating curve, Acrobeles spp. were more abundant than Cephalobus spp., in almost all months. The population of Acrobeles spp. declined from May to October, the post harvest period and during all of the dry season, and peaked in the rainy season, from November to
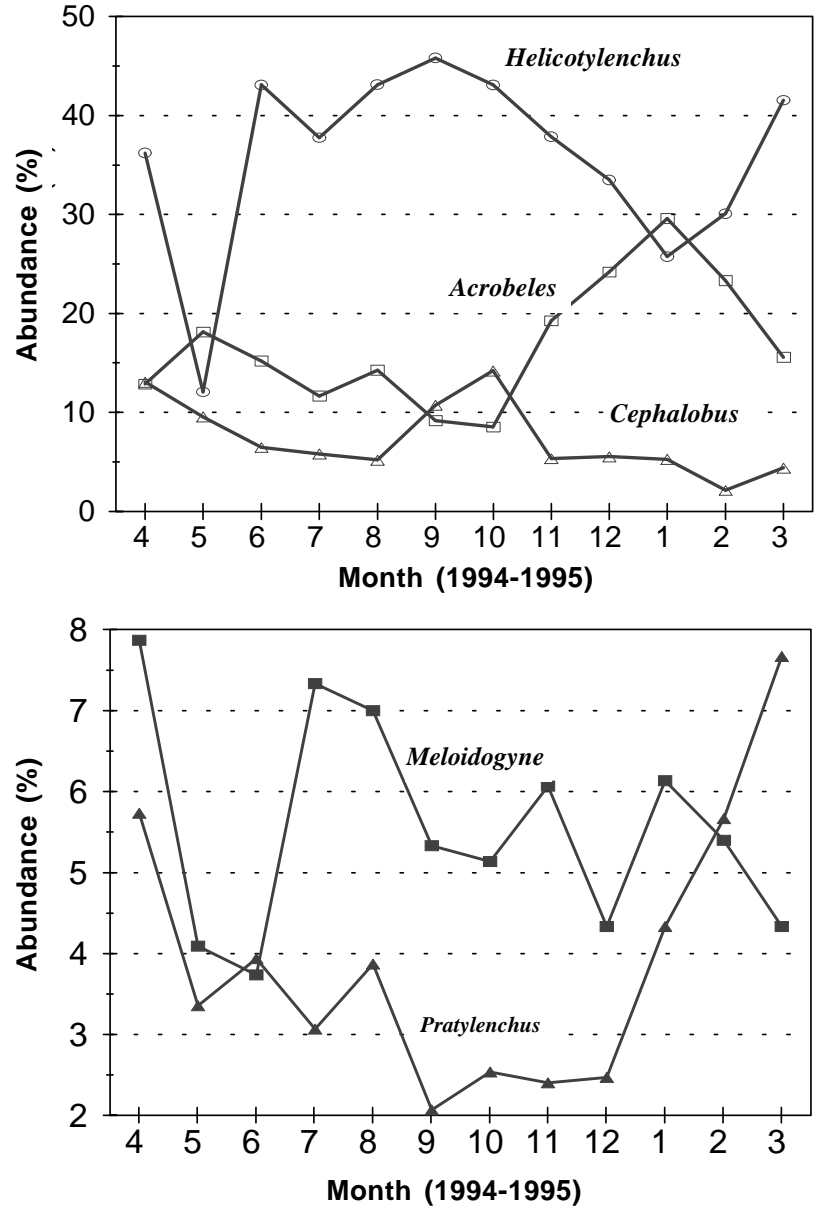

FIG. 5 - Population fluctuations of Helicotylenchus spp., Acrobeles spp., Cephalobus spp., Meloidogyne spp. and Pratylenchus spp. collected monthly from three soybean (Glycine max) fields in the temporal sampling for 12 months in PAD/DF, the major soybeangrowing region of Brazilian Federal District.

March, whereas that of Cephalobus spp. maintained a stable level all year around, except for a peak in October, the last dry month with the lowest soil water content (below 15\%), and showed its lowest level in February, one of the wettest months. Also, soil water contents were related positively to Acrobeles spp. $(r=0.67)$ and negatively to Cephalobus spp. $(r=-0.62)$. The above facts indicate that Acrobeles spp. adapted well in wet soil (over 17\%), whereas Cephalobus spp. survived better in dry soil (below $15 \%$ of soil water content), thus showing a negative correlation $(r=-0.62)$ between the two nematodes.

The influence of soil water contents and annual precipitation on nematode populations has been well documented (Norton, 1978). Soil water content was mostly from annual precipitation because all soybean fields in the PAD/DF were not irrigated. But both showed a low degree of relationship to each other $(r=0.38)$, possibly due to soil texture being red latossol characterized by low capacity of water retention. It may explain why there were higher relations between soil water contents and nematodes than these between annual precipitation and nematodes. 
Nematode community, trophic structure and population fluctuation in soybean fields

TABLE 3 - Correlation coefficient ${ }^{\star}$ among the abundance (\%) of the five trophic groups (A), and of the five most abundant nematodes (B) with soil water content, and precipitation, in three soybean (Glycine max) fields from PAD/DF, the Brazilian central region during 1994-1995

\begin{tabular}{|c|c|c|c|c|c|c|}
\hline$\overline{\mathrm{A}}$ & $\overline{\text { PP\& }}$ & BF & $\overline{\mathbf{F F}}$ & $\overline{\mathbf{P R}}$ & $\overline{\mathrm{OM}}$ & soil water content \\
\hline$\overline{\mathrm{BF}}$ & $-0.39^{\#}$ & 1 & & & & \\
\hline FF & $-0.93 *$ & 0.13 & 1 & & & \\
\hline PR & $-0.63 *$ & -0.29 & $0.62 *$ & 1 & & \\
\hline OM & -0.08 & $-0.46^{*}$ & 0.03 & $0.47 *$ & 1 & \\
\hline soil water content & $-0.48 *$ & $0.54 *$ & 0.33 & 0.04 & -0.02 & 1 \\
\hline precipitation & 0.07 & 0.09 & -0.28 & 0.07 & $0.48^{*}$ & 0.38 \\
\hline
\end{tabular}

\begin{tabular}{|c|c|c|c|c|c|c|}
\hline$\overline{\mathbf{B}}$ & Helicotylenchus & Acrobeles & Cephalobus & Meloidogyne & Pratylenchus & soil water content \\
\hline Acrobeles & $-0.60^{*}$ & 1 & & & & \\
\hline Cephalobus & 0.12 & $-0.62 *$ & 1 & & & \\
\hline Meloidogyne & 0.19 & -0.07 & -0.20 & 1 & & \\
\hline Pratylenchus & -0.06 & 0.25 & $-0.56^{*}$ & -0.19 & 1 & \\
\hline soil water content & -0.29 & $0.67 *$ & $-0.62 *$ & $-0.41 *$ & $0.48 *$ & 1 \\
\hline precipitation & -0.12 & $0.65 *$ & $-0.41 *$ & -0.24 & 0.31 & 0.38 \\
\hline
\end{tabular}

\& results of 36 pairs of data in the analyses of Pearson's correlation coefficient.

\# $\mathrm{PP}=$ plant parasites, $\mathrm{BF}=$ bacterial feeders, $\mathrm{FF}=$ fungal feeders, $\mathrm{PR}=$ predator, and $\mathrm{OM}=$ omnivores.

$* p<0.05$.

In conclusion, the results of most of the ecological measurements from the two sampling types were not different, except that the temporal sampling detected more rare nematodes than the spatial sampling did. Three plant parasite genera (Helicotylenchus, Meloidogyne, and Pratylenchus) and two bacterivores (Acrobeles and Cephalobus) dominated nematode communities, and $H$. glycines were not found in this region. The population fluctuation of plant parasitic nematodes was connected with plant growth in fields. The fluctuation of bacterivores was related to periodic changes of soil water content, and that of fungivores were associated with fungal root decomposition in soil. Annual population patterns of the five genera were related to seasonal changes of soil water contents and to soybean growing and fallowing periods, in which Acrobeles spp. and Pratylenchus spp. populated more in wet soils, Cephalobus spp. and Meloidogyne spp. adapted well in dry soils, but Helicotylenchus spp. survived abundantly in wide ranges of soil moisture.

\section{LITERATURE CITED}

BONGERS, T. The maturity index: an ecological measure of environmental disturbance based on nematode species composition. Oecologia 83:14-19. 1990.

BOSTRÖM, S. \& SOHLENIUS, B. Short-term dynamics of nematode communities in arable soil: influence of a perennial and annual cropping system. Pedobiologia 29:345-357. 1986.

CARES, J.H. \& HUANG, S.P. Nematode fauna in natural and cultivated cerrados of Central Brazil. Fitopatologia Brasileira 16:199209. 1991.

COLEMAN, D.C., EDWARDS, A.L., BELSKY, A.J. \& MWONGA, $S$. The distribution and abundance of soil nematodes in East African savannas. Biology and Fertility of Soils 12:67-72. 1991.

CONAB/DIPLA. Soja: área, produção e produtividade-evolução da produção de soja no Brasil. www.cnpso.embrapa.br. 2002.

EMBRAPA. Levantamento de reconhecimento dos solos do DF. Boletim Técnico no 53. Serviço Nacional de Levantamento e Conservação de Solos, Rio de Janeiro, RJ. 1978. 451p.

FRECKMAN, D.W. Parameters of the nematode contribution to ecosystems. In: Freckman, D.W. (Ed.) Nematodes in soil ecosystems, p.81-97. University of Texas Press, Austin. 1982.

FRECKMAN, D.W. \& ETTEMA, C.H. Assessing nematode communities in agroecosystems of varying human intervention. Agricultural Ecosystems \& Environment 45:239-261. 1993.

GOELLNER, G.F. Aspectos econômicos do nematóide do cisto na sojicultura brasileira. In: Programa e Anais do Congresso Internacional de Nematologia Tropical-XIX Congresso da Sociedade Brasileira de Nematologia and XXII Congresso da Organização dos Nematologistas da América Tropical, Rio Quente, Brasil, Junho 4-9. 1995. pp.102-106.

GOMES, G.S. Biodiversidade e caracterização da estrutura de comunidades de nematóides em campos de soja (Glycine max Merr) no Distrito Federal (Tese de Mestrado). Universidade de Brasília, Brasília. 1996.

HOPPER, D.J. Handling, fixing, staining and mountaing nematodes. In: Southey, J.F. (Ed.) Laboratory methods for work with plant and soil nematodes. Commonwealth Agricultural Bureaux, Herts, Technology Bulletim 2:39-54. 1970.

HUANG, S.P. \& PORTO, M.V.F. Efeito do alqueive na população dos nematóides das galhas e na produção de cenoura. Fitopatologia Brasileira 13:377-381. 1988.

HYVONEN, R. \& PERSSON, T. Effects of acidification and liming on feeding groups of nematodes in coniferous forest soils. Biology Fertility Soils 9:205-210. 1990.

KREBS, C.J. Ecology: the experimental analysis of distribution and abundance (fourth edition). Harper Collins College Publishers, New York. 1994. 801p.

MAGURRAN, A.E. Ecological diversity and its measurement. University Press, Cambidge, UK. 179 pp. 1988. 
McSORLEY, R. \& FREDERICK, J.J. Nematode community structure in rows and between rows of a soybean field. Fundamental \& Applied Nematology 19:251-261. 1996.

NEHER, D.A. \& CAMPBELL, C.L. Nematode communities and microbial biomass in soils with annual and perennial crops. Applied Soil Ecology 1:17-28. 1994.

NIBLACK, T.L. Aplication of nematode community structure research to agricultural production and habitat disturbance. Journal of Nematology 21:437-443. 1989.

NORTON. D.C. Ecology of plant parasitic nematodes. John Wiley \& Sons. New York. 1978. 268p.

SAMOILOFF, M.R. Nematodes as indicator of toxic environmental contaminants. In: Veech, J.A. \& Dickson, D.W. (Eds) Vistas on Nematology, p.433-439. Society of Nematologists, Inc. E.O. Painter Printing Co, DeLeon Springs, Florida. 1987.

SASSER, J.N. Economic importance of Meloidogyne in tropical countries. In: Lamberti, F. \& Taylor, C.E. (Eds.) Root-knot nematodes (MELOIDOGYNE species) Systematics, biology and control, p.359-374. Academic Press, New York. 1979.
SEINHORST, J.W. A rapid method for the transfer of nematodes from fixative to anhydrous gylcerine. Nematologica 4:67-69. 1959. SILVA, J.F.V. Um histórico. In: Azevedo, L. (Ed.) O nematóide de cisto da soja: a experiência brasileira, pp.5-23. Sociedade Brasileira de Nematologia, Jaboticabal, São Paulo, 1999.

SOHLENIUS, B. \& SANDOR, A. Ploughing of a perennial grass ley-effect on the nematode fauna. Pedobiologia 33:199-210. 1987.

SOHLENIUS, B. \& WASILEWSKA, L. Influence of irrigation and fertilization on the nematode community in a Swedish pine forest soil. Journal of Applied Ecology 21:327-342. 1984.

THOMAS, S.H. Population densities of nematodes under seven tillage regimes. Journal of Nematology 10:24-27. 1978.

WASILEWSKA, L. Long-term changes in communities of soil nematodes on fen peat meadows due to the time since their drainage. Ekologia Polska 2/39:59-104. 1991.

YEATES, G.W., BONGERS, T., GOEDE, R.G.M. DE, FRECKMAN, D.W. \& GEORGIEVA, S.S. Feeding habits in soil nematodes families and genera-an outline for soil ecologists. Journal of Nematology 25:315-331. 1993. 